\title{
Laryngeal Cancer pN2c TNM Finding v8
}

National Cancer Institute

\section{Source}

National Cancer Institute. Laryngeal CancerpN2c TNM Finding v8. NCI Thesaurus. Code C133146.

Laryngeal cancer with metastasis in bilateral or contralateral lymph nodes, none more than $6 \mathrm{~cm}$ in greatest dimension and ENE(-). (from AJCC 8th Ed.) 